\title{
Relationship between Serum Sex Hormone Concentrations and Histology of Seminiferous Tubules of Captured Baleen Whales in the Western North Pacific during the Feeding Season
}

\author{
Hiroyuki WATANABE ${ }^{1)}$, Toshihiro MOGOE ${ }^{3)}$, Masatsugu ASADA ${ }^{1)}$, \\ Kengo HAYASHI ${ }^{2)}$, Yoshihiro FUJISE ${ }^{3)}$, Hajime ISHIKAWA ${ }^{3)}$, Seiji OHSUMI ${ }^{3)}$, \\ Akio MIYAMOTO ${ }^{2)}$ and Yutaka FUKUI ${ }^{1)}$ \\ ${ }^{1)}$ Department of Animal Production Science, ${ }^{2)}$ Department of Agricultural and Life Science, \\ Obihiro University of Agriculture and Veterinary Medicine, Obihiro 080-8555, ${ }^{3)}$ The Institute \\ of Cetacean Research, Tokyo 104-0055, Japan
}

\begin{abstract}
The present study was conducted to obtain new information on relationships among serum testosterone $(\mathrm{T})$, estradiol-17 $\beta\left(\mathrm{E}_{2}\right)$, follicle-stimulating hormone $(\mathrm{FSH})$, and luteinizing hormone $(\mathrm{LH})$ concentrations and histology of seminiferous tubules in captured common minke and Bryde's whales during the feeding season. Blood samples and testes were collected from common minke $(\mathrm{n}=39$ for blood samples, $n=15$ for testes) and Bryde's ( $n=14$ for blood samples, $n=7$ for testes) whales captured from May 2001 to August 2001 in the Western North Pacific. Serum T concentrations, in 35.9\% of the common minke and $57.1 \%$ of Bryde's whales, were below the detection limit $(<2.5 \mathrm{pg} / \mathrm{ml})$. There were no significant differences in the serum concentrations of $\mathrm{E}_{2}, \mathrm{FSH}$, and $\mathrm{LH}$ among immature, mature common minke and Bryde's whales except that LH levels of immature Bryde's whales was higher than those of common minke whales. In most seminiferous tubules of mature whales, only a single-layer of spermatogonia was observed. However, spermatozoa were observed in seminiferous tubules in 2/13 of mature common minke and 4/4 of mature Bryde's whales with the low or undetectable $\mathrm{T}$ levels. These results indicate that the low serum $\mathrm{T}$ concentrations reflect the inactivity of spermatogenesis in both baleen whales, and that it is not possible to assess gonadal activity in either common minke or Bryde's whales using serum sex hormone concentrations during the feeding season.
\end{abstract}

Key words: Whale, Testis, Steroid hormone, FSH, LH

(J. Reprod. Dev. 50: 419-427, 2004)

B aleen whales seem to be seasonal breeders that live in high latitudinal sea areas during the feeding season in summer and in low latitudinal sea areas during the breeding season in winter. The current methods of investigating ecology and reproduction of wild cetaceans in Japan are restricted to use of stranded whales, or whales captured by a vessel of the Japanese Whale

Accepted for publication: March 24, 2004

Correspondence: Y. Fukui (e-mail: fukui@obihiro.ac.jp)
Research Program under Special Permit in the Western North Pacific (JARPN II) and in the Antarctic (JARPA). In the research programs, mainly baleen whales including common minke (Balaenoptera acutorostrata), Antarctic minke (Balaenoptera bonaerensis) and Bryde's (Balaenoptera edeni) whales have been captured to obtain biological parameters for management of the whale population. In Antarctic minke whales, various studies on spermatozoa and oocytes have been 
reported [1, 2]. However, it has been difficult to clarify reproductive characteristics due to the limited number of whales captured during the feeding season.

Recent studies about zygotes of domestic animals including cattle and sheep have investigated many different reproductive technologies. Asada et al. [3] showed that immature oocytes taken from captured Antarctic minke whales could be matured and fertilized in vitro successfully. However, the culture conditions did not seem to be optimal. Sperm morphology and sperm concentration per ejaculation are different among individual mammalian species. In general, sperm characteristics of motility, viability and abnormality affect normal fertilization in vivo and in vitro, but descriptions of them are extremely rare in baleen whales [4].

In testis, differentiation of spermatogonia in seminiferous tubules depends on age and season in seasonally breeding animals. Spermatocytes located in the basal layers move into the lumen during spermatogenesis. Finally, transformation from spermatid to spermatozoa occurs to complete spermatogenesis. Spermatogenesis in terrestrial mammals is controlled by gonadotropin releasing hormone released from the hypothalamus, gonadotropins released from the pituitary and steroid hormones released from the testis: folliclestimulating hormone (FSH), luteinizing hormone $(\mathrm{LH})$, testosterone $(\mathrm{T})$ and estradiol-17 $\beta\left(\mathrm{E}_{2}\right)$. In rams, although semen volume and sperm motility increase, and sperm abnormality decreases as the breeding season approaches, it was possible to collect motile spermatozoa during the nonbreeding season [5]. In bucks, also, sperm production increases during the breeding season, but it is maintained to a certain extent during the non-breeding season [6]. It is known that in baleen whales, sperm production is extremely low during the non-breeding season [7]. However, detailed information about sperm production and endocrinological circumstances during the nonbreeding season in baleen whales is not available to date.

The present study was conducted to investigate the reproductive characteristics of two species of baleen male whales (common minke and Bryde's whales) captured in the Western North Pacific during the feeding season, especially the relationships between serum sex hormone concentrations and histology of seminiferous tubules for the evaluation of sperm production. The post freezing-thawing sperm characteristics of a Bryde's whale were also examined.

\section{Materials and Methods}

The present study was approved by the Animal Experimental Committee of Obihiro University of Agriculture and Veterinary Medicine, in accordance with the Guiding Principles for the Care and Use of Research Animals.

\section{Animals}

Thirty-nine male common minke and 14 Bryde's whales captured for JARPN II between May 2001 and August 2001 were used in this study. The animals were sampled in subareas 7,8 , and 9excluding the EEZ of foreign countries-which were established by the International Whaling Commission (IWC). All whales used in the present study were killed by explosive harpoons which have been recognized as the best humane killing method of whales by the IWC and provided by Schedule III (Capture) of the International Convention for the Regulation of Whaling. Special attention to reduce the time to death was given to all sampled whales; explosive harpoons for the primary method and large caliber rifle as the secondary method when required. Body length and body weight were measured on board the vessel immediately after death. Collected blood samples and removed testes and spermatic ducts were kept without seawater contamination. Testes removed from blood and connective tissue were weighed. Common minke whales having one testis weighing $400 \mathrm{~g}$ or over were considered to be sexually mature [8]. Similarly, Bryde's whales having one testis weighing $750 \mathrm{~g}$ or over were considered to be sexually mature [9].

\section{Hormonal assay}

Blood samples of 39 common minke and 14 Bryde's whales were collected from the upper jaw or fin. The samples were centrifuged (3000 rpm for $10 \mathrm{~min}$ ) within $1 \mathrm{~h}$ of collection, stored at $-30 \mathrm{C}$ until assay for serum $\mathrm{T}, \mathrm{E}_{2} \mathrm{FSH}$ and $\mathrm{LH}$ concentrations. The serum concentrations of $\mathrm{T}, \mathrm{E}_{2}$, FSH and LH in each whale were determined in duplicate by enzyme immunoassays (EIAs) using 
96-well ELISA plates. Serum concentrations of steroids ( $\mathrm{T}$ and $\mathrm{E}_{2}$ ) were determined after diethylether extraction. The EIA for $\mathrm{T}$ has been described previously [10]. The standard curve ranged from 0.025 to $25 \mathrm{ng} / \mathrm{ml}$, and the $\mathrm{ED}_{50}$ of the assay was $1.55 \mathrm{ng} / \mathrm{ml}$. The intra- and inter-assay CVs were 6.8 and $8.7 \%$, respectively. The EIA for $\mathrm{E}_{2}$ was carried out as described previously [11]. The standard curve ranged from 2 to $2000 \mathrm{pg} / \mathrm{ml}$, and the $\mathrm{ED}_{50}$ of the assay was $110 \mathrm{pg} / \mathrm{ml}$. The intra- and inter-assay CVs were 6.3 and $8.5 \%$, respectively. The recovery rates of $\mathrm{T}$ and $\mathrm{E}_{2}$ were $80 \%$ and $73 \%$, respectively. In the extraction process, the samples were concentrated 10-fold, so the detection limit of this system was $0.0025 \mathrm{ng} / \mathrm{ml}$ for $\mathrm{T}$ and $0.2 \mathrm{pg} / \mathrm{ml}$ for $E_{2}$. The EIA for FSH was measured by a modification of the method previously reported by Watanabe et al. [12] and Suzuki et al. [13]. In the FSH assay, ovine FSH (USDA-oFSH-SIAFP-RP-2) as the standard, and a polyclonal antibody against human FSH (M-91) were used. The standard curve ranged from 0.097 to $100 \mathrm{ng} / \mathrm{ml}$ and the $\mathrm{ED}_{50}$ of the assay was $11.2 \mathrm{ng} / \mathrm{ml}$. The intra- and inter-assay CVs were 13.5 and $16.9 \%$, respectively. The EIA for LH determination was based on the method by Mutayoba et al. [14]. In the LH assay, rat LH (NIDDK-rLH-RP-3) as the standard, and a polyclonal antibody against rat LH were used as reported by Suzuki et al. [13]. The standard curve ranged from 0.2 to $200 \mathrm{ng} / \mathrm{ml}$ and the $\mathrm{ED}_{50}$ of the assay was $18.6 \mathrm{ng} / \mathrm{ml}$. The intra- and inter-assay CVs were 8.7 and $14.0 \%$, respectively.

\section{Histological observation}

The right testes of 15 common minke and 7 Bryde's whales accompanied with collected blood samples were cut in the center, and a piece of tissue $(3 \times 3 \mathrm{~cm})$ was fixed immediately in $10 \%$ formalin for histological examination. After testis samples were brought to the laboratory, they were embedded in paraffin. Four micron sections of samples were made, and stained with hematoxylin and eosin. The slides were observed by light microscopy. The number of seminiferous tubules was determined as the mean number of 6 different microscopic fields $(\times 100)$ per whale. Only tubules surrounded with the basal layer were selected for measurement. The diameter of seminiferous tubules was estimated by taking the mean diameter of 20 tubules per whale. Only circular crosssectioned tubules were selected for measurement.
An ocular micrometer was used for the measurement of each tubule diameter. The number of spermatozoa was counted in 50 serial tubules and was calculated by taking the mean number of 6 different microscopic fields per whale.

\section{Freezing of spermatozoa}

Spermatozoa were recovered from the vasa deferentia of one of the captured Bryde's whales. It was frozen, following a method described in a previous study [2]. The collected fluid containing spermatozoa $(0.5 \mathrm{ml})$ was diluted with $4.5 \mathrm{ml}$ of a warmed $(30 \mathrm{C})$ diluent $(300 \mathrm{mM}$ Tris aminomethane, $94.75 \mathrm{mM}$ citric acid, $27.75 \mathrm{mM}$ glucose, $15 \% \mathrm{v} / \mathrm{v}$ egg-yolk, $5 \% \mathrm{v} / \mathrm{v}$ glycerol). After mixing, the diluted sperm samples were cooled in a $5 \mathrm{C}$ refrigerator for $2 \mathrm{~h}$. Aliquots $(0.3-0.4 \mathrm{ml})$ of the cooled sperm samples were then introduced into sterilized microtubes and placed in an $-80 \mathrm{C}$ deepfreezer. After freezing they were kept in a deepfreezer until the vessel returned to port, at which time they were stored in liquid nitrogen. The samples in liquid nitrogen were then transported to the laboratory.

\section{Sperm evaluation under a light microscope}

Frozen Bryde's spermatozoa were taken out from liquid nitrogen, kept for a few seconds at room temperature, and then immersed into a water bath at $37 \mathrm{C}$. After thawing, the percentage of motile spermatozoa (sperm motility), the proportion of live spermatozoa (sperm viability), sperm concentration and sperm abnormality were determined. Sperm motility was subjectively assessed under a coverslip on a prewarmed (37 C) slide using a phase contrast microscope $(\times 100)$. Sperm viability and sperm abnormality were estimated in air-dried smears, after staining with $1.7 \%$ eosin and $10.0 \%$ nigrosin containing $2.9 \%$ trisodium citrate dehydrate, using a light microscope ( $\times 400)$. Sperm viability and abnormality were calculated three times by counting 200 spermatozoa. Finally, sperm concentration was determined using a haemocytemeter.

\section{Statistical analysis}

Hormonal data were analyzed by analysis of variance followed by Scheffe's method and testicular histological data were analyzed by Student's t-test. Differences were considered significant when $\mathrm{P} \leq 0.05$. 


\section{Results}

\section{Serum hormone concentrations}

Twenty-eight out of 39 common minke and 4 out of 14 Bryde's whales were determined as sexually mature by their single testis weight. Serum T concentrations and testis weights are shown in Table 1. Serum T concentrations of 14/39 (35.9\%) common minke and 8/14 (57.1\%) Bryde's whales were below the detectable value $(<2.5 \mathrm{pg} / \mathrm{ml})$. In whales' measured serum $\mathrm{T}$ concentrations, the levels were low in both immature (common minke, $0.1 \pm 0.1 \mathrm{ng} / \mathrm{ml}$, Bryde's, $0.2 \pm 0.1 \mathrm{ng} / \mathrm{ml})$ and mature (common minke, $0.1 \pm 0.0 \mathrm{ng} / \mathrm{ml}$, Bryde's, $0.4 \pm 0.2 \mathrm{ng} / \mathrm{ml}$ ) whales. Serum $\mathrm{E}_{2}, \mathrm{FSH}$ and LH concentrations are shown in Table 2. There were no significant differences in the serum $\mathrm{E}_{2}, \mathrm{FSH}$ and $\mathrm{LH}$ concentrations between mature common minke and Bryde's whales. However, the serum LH concentrations of immature Bryde's whales (5.6 \pm $0.2 \mathrm{ng} / \mathrm{ml})$ were significantly $(\mathrm{P}<0.05)$ higher than those of immature $(4.5 \pm 0.2 \mathrm{ng} / \mathrm{ml})$ and mature $(4.5$ $\pm 0.2 \mathrm{ng} / \mathrm{ml}$ ) common minke whales. Also, in both common minke and Bryde's whales, serum $\mathrm{E}_{2}, \mathrm{FSH}$ and LH concentrations were not significantly different between immature and mature whales.

\section{Histological observation}

The histological sections of testis of 15 common minke and 7 Bryde's whales were examined. Thirteen common minke and 4 Bryde's whales were determined as sexually mature. The results of seminiferous tubule number and diameter are shown in Table 3. The result of immature common minke whales was not used for statistical analysis, because of the small number of samples $(n=2)$. The mean seminiferous tubule number of mature common minke whales was significantly higher than that of mature Bryde's whales $(\mathrm{P}<0.05)$. Also, the mean seminiferous tubule number was higher in immature Bryde's whales than that of mature Bryde's whales $(\mathrm{P}<0.05)$. The mean seminiferous tubule diameter of mature Bryde's whales was significantly larger than that of mature common minke whales $(\mathrm{P}<0.05)$, and it was also significantly larger in mature Bryde's whales than in immature Bryde's whales $(\mathrm{P}<0.05)$. The number of spermatozoa in seminiferous tubules is shown in Table 4. Spermatozoa were observed in two out of 13 mature common minke whales, whereas spermatozoa were observed in all 4 mature Bryde's whales. Also, regardless of either detectable or undetectable levels of serum T concentrations, spermatozoa were observed in both common minke and Bryde's whales. As shown in Fig. 1, the lumens were observed in seminiferous tubules of immature and mature common minke, and mature Bryde's whales, but no lumen was observed in

Table 1. Serum $\mathrm{T}$ concentrations in common minke and Bryde's whales with different maturities

\begin{tabular}{llccc}
\hline \multicolumn{1}{c}{ Species } & Maturity $(\mathrm{N})$ & $\begin{array}{c}\text { Testis weight } \\
(\mathrm{g}: \text { Mean } \pm \text { SEM) }\end{array}$ & $\begin{array}{c}\text { T-detectable individuals* } \\
(\%)\end{array}$ & $\begin{array}{c}\text { T } \\
(\mathrm{ng} / \mathrm{ml}: \text { Mean } \pm \text { SEM) }\end{array}$ \\
\hline \multirow{2}{*}{ Common Minke } & Mature (28) & $737.8 \pm 44.4$ & $17 / 28(60.7)$ & $0.1 \pm 0.0$ \\
& Immature (11) & $152.0 \pm 34.8$ & $8 / 11(72.7)$ & $0.1 \pm 0.1$ \\
\hline \multirow{2}{*}{ Bryde's } & Mature (4) & $1847.0 \pm 583.3$ & $3 / 4(75.0)$ & $0.4 \pm 0.2$ \\
& Immature (10) & $174.3 \pm 41.1$ & $3 / 10(30.0)$ & $0.2 \pm 0.1$ \\
\hline
\end{tabular}

$\mathrm{N}$ : Number of animals examined.

* Detection limit: $2.5 \mathrm{pg} / \mathrm{ml}$.

Table 2. Serum $\mathrm{E}_{2}, \mathrm{FSH}$ and $\mathrm{LH}$ concentrations (Mean $\pm \mathrm{SEM}$ ) in common minke and Bryde's whales with different maturities

\begin{tabular}{llccc}
\hline \multicolumn{1}{c}{ Species } & Maturity $(\mathrm{N})$ & $\mathrm{E}_{2}(\mathrm{pg} / \mathrm{ml})$ & $\mathrm{FSH}(\mathrm{ng} / \mathrm{ml})$ & $\mathrm{LH}(\mathrm{ng} / \mathrm{ml})$ \\
\hline \multirow{2}{*}{ Common Minke } & Mature (28) & $1.5 \pm 0.1$ & $4.3 \pm 0.3$ & $4.5 \pm 0.2^{\mathrm{a}}$ \\
& Immature (11) & $1.8 \pm 0.2$ & $4.7 \pm 0.3$ & $4.5 \pm 0.2^{\mathrm{a}}$ \\
\hline \multirow{2}{*}{ Bryde's } & Mature (4) & $1.4 \pm 0.2$ & $5.3 \pm 0.3$ & $5.0 \pm 0.2^{\mathrm{ab}}$ \\
& Immature (10) & $11.3 \pm 0.2$ & $4.6 \pm 0.4$ & $5.6 \pm 0.2^{\mathrm{b}}$ \\
\hline
\end{tabular}

$\mathrm{N}$ : Number of animals examined.

a, b: Significantly different between different superscripts $(\mathrm{P}<0.05)$. 
Table 3. Number and diameter of seminiferous tubules in common minke and Bryde's whales with different maturities

\begin{tabular}{llcc}
\hline \multirow{2}{*}{ Species } & Maturity $(\mathrm{N})$ & \multicolumn{2}{c}{ Seminiferous tubule (Mean \pm SEM) } \\
\cline { 3 - 4 } & & Number & Diameter $(\mu \mathrm{m})$ \\
\hline \multirow{2}{*}{ Common Minke } & Mature (13) & $84.6 \pm 4.5^{\mathrm{A}}$ & $142.7 \pm 2.9^{\mathrm{A}}$ \\
& Immature (2) & $85.7 \pm 3.0$ & $127.9 \pm 7.4$ \\
\hline \multirow{2}{*}{ Bryde's } & Mature (4) & $64.3 \pm 8.2^{\mathrm{Ba}}$ & $179.8 \pm 11.8^{\mathrm{Ba}}$ \\
& Immature (3) & $314.2 \pm 35.1^{\mathrm{b}}$ & $68.2 \pm 3.4^{\mathrm{b}}$ \\
\hline
\end{tabular}

$\mathrm{N}$ : Number of animals examined.

A,B; a,b: Significantly different between different superscripts $(\mathrm{P}<0.05)$.

* Excluded from statistical analysis.

Table 4. Serum $\mathrm{T}$ concentration and number of spermatozoa in seminiferous tubules in common minke and Bryde's whales

\begin{tabular}{ccc}
\hline Species & $\mathrm{T}(\mathrm{ng} / \mathrm{ml})^{* *}$ & $\begin{array}{c}\text { Sperm number } \\
\text { (Mean } \pm \text { SEM) }\end{array}$ \\
\hline Common Minke $(2 / 13)^{*}$ & UD & $7.0 \pm 1.3$ \\
& UD & $3.5 \pm 0.6$ \\
\hline & 0.643 & $25.0 \pm 3.6$ \\
${\text { Bryde's }(4 / 4)^{*}}^{*}$ & 0.665 & $8.3 \pm 1.1$ \\
& 0.006 & $34.3 \pm 3.0$ \\
& UD & $32.2 \pm 7.1$ \\
\hline
\end{tabular}

* Number of whales with spermatozoa/number of mature whales examined

** UD: $<2.5 \mathrm{pg} / \mathrm{ml}$.

Sperm number: Measured in 50 tubules per whale.

seminiferous tubules of immature Bryde's whales. In most seminiferous tubules examined, only a single-layer of spermatogonia was observed and Sertoli cells were located in this layer.

\section{Sperm characteristics}

Spermatozoa were recovered from a Bryde's whale with spermatozoa in the seminiferous tubule. A representative of post-thawing spermatozoon is shown in Fig. 2. Sperm motility was below $5 \%$. The mean sperm concentration was $51.3 \pm 4.7 \times 10^{6}$ cells $/ \mathrm{ml}$, and sperm viability after staining with eosin-nigrosin was $20.0 \pm 2.3 \%$. The proportion of abnormal spermatozoa was $37.5 \pm$ $5.0 \%$. Also, in sperm head morphology, conical or elliptic forms were mainly observed.

\section{Discussion}

The present study is the first report presenting the serum sex hormone concentrations of Bryde's whale during the feeding season. In the present study, sexual maturity could not be determined using serum hormone concentrations in captured common minke and Bryde's whales during the feeding season. However, the present results have demonstrated that spermatozoa exist in seminiferous tubules of common minke and Bryde's whales during the feeding season. Also, motile spermatozoa (less than 5\%) of Bryde's whale were recovered after freezing and thawing.

In the present study, single testis weight was used for classification of sexual maturity in common minke and Bryde's whales, as previously reported $[8,9]$, and the presence of spermatozoa in seminiferous tubules was considered proof of sexual maturity of the whale. A criterion reported in Antarctic minke whales (single testis weight: 400 $\mathrm{g}$ or over) was used in common minke whales in this study, but the single testis weights showed a large variance ( $675 \mathrm{~g}$ and $860 \mathrm{~g}$ ) between two common minke whales with spermatozoa in seminiferous tubules in this study. Also, the weights of single testis in immature (range: 41-345 g) and mature (range: 801-3664 g) Bryde's whales were greatly different.

In common minke whales, although statistical analysis could not be conducted due to the small number of testis samples of immature whales, the measurements of seminiferous tubules showed similar values between immature and mature whales. We consider that common minke whales judged to be immature in this study may have been close to sexually mature status. Therefore, determination of whether or not a whale is sexually mature may be difficult by measurement of only a single testis weight.

Christensen [15] reported age determination by 

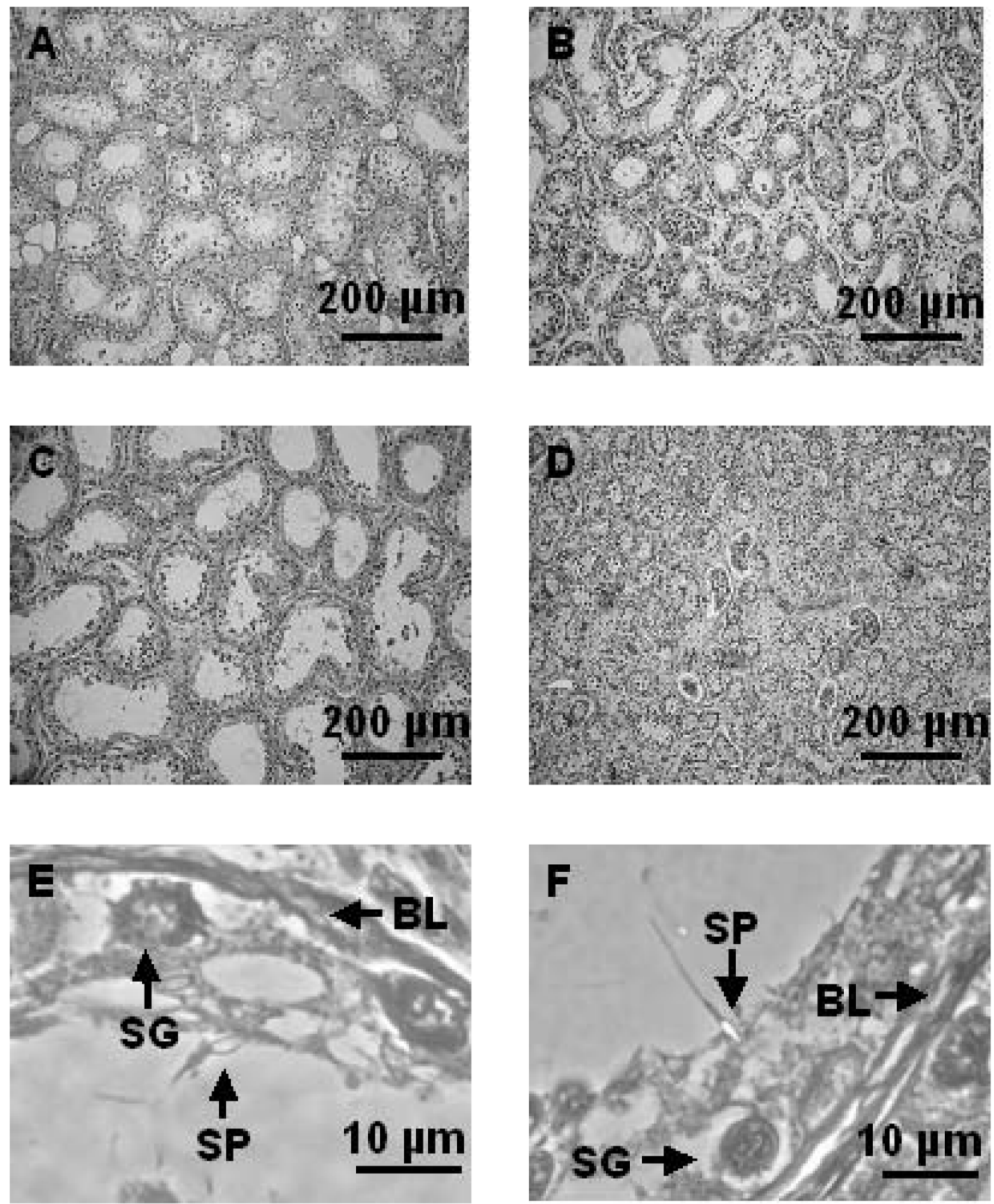

Fig. 1. Histological sections of seminiferous tubules in common minke and Bryde's whales. A: a mature common minke whale, B: an immature common minke whale, $\mathrm{C}$ : a mature Bryde's whale, D: an immature Bryde's whale, E: a mature common minke whale with a spermatozoon, F: a mature Bryde's whale with a spermatozoon, SP: sperm, SG: spermatogonia, BL: basal layer.

the body length of the common minke whales. Sexual maturity of short-finned [16] and longfinned [17] pilot whales was estimated by the proportion of mature seminiferous tubules. In future studies, more appropriate indicators such as a combination of body length, testis weights and maturity of seminiferous tubules, should be investigated to determine sexual maturity in common minke and Bryde's whales.
Small cats maintain spermatogenic activity with more than $2.1 \pm 0.5 \mathrm{nmol} / 1$ in serum $\mathrm{T}$ concentrations throughout the year [18]. In longfinned pilot whales [17] and fin whales [19], it was reported that $\mathrm{T}$ concentrations reflect gonadal activity in males. On the other hand, serum $\mathrm{T}$ concentrations varied from 0.05 to $0.35 \mathrm{ng} / \mathrm{ml}$ in Antarctic minke whales during the feeding season [20]. Yoshioka and Fujise [21] and Suzuki et al. [13] 

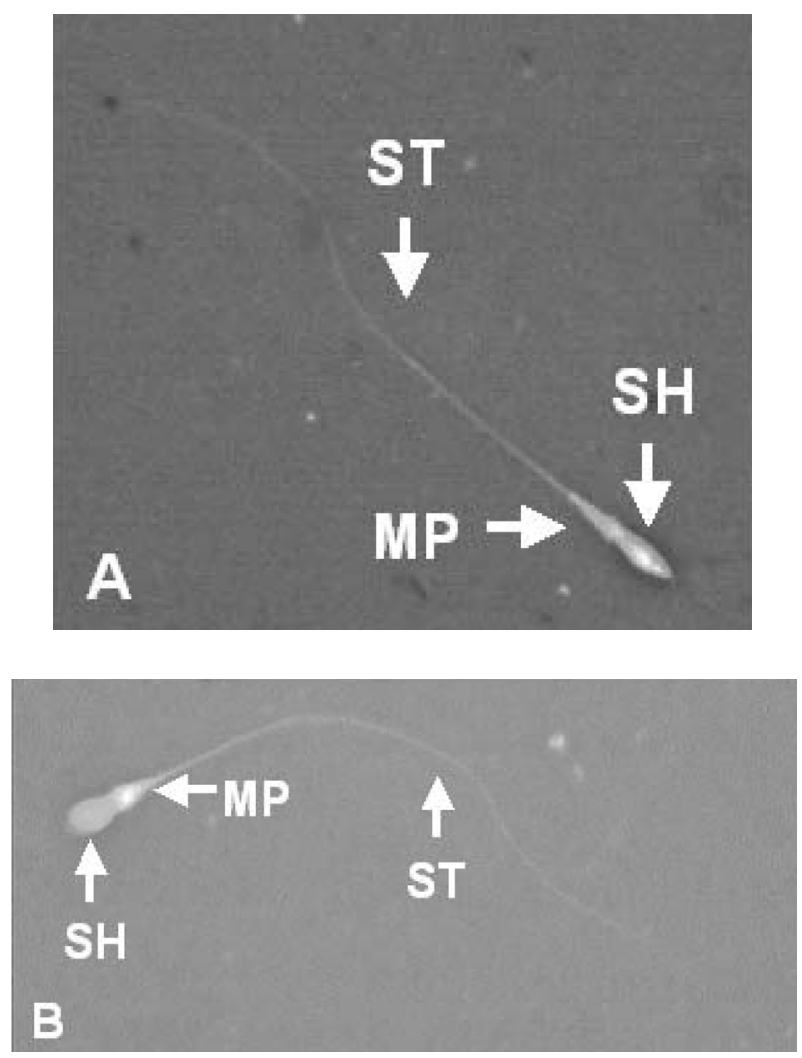

Fig. 2. A post-thawing spermatozoon of a Bryde's whale after staining with eosin-nigrosin. $\mathrm{SH}$ : sperm head, MP: mid-peace, ST: tail, A: sperm head with conical form, B: sperm head with elliptic form.

reported that low serum $\mathrm{T}$ concentrations suggest low gonadal activity in male Antarctic minke whales during the feeding season. The serum $\mathrm{T}$ concentrations in the present study were similar to previous results [13, 20, 21]. Suzuki et al. [13] measured plasma $\mathrm{E}_{2}, \mathrm{FSH}$ and $\mathrm{LH}$ concentrations in Antarctic minke whales, and reported that plasma $\mathrm{E}_{2}$ concentrations reflected depression of reproductive activity in mature male whales during the feeding season. In the present study, there were no significant differences in serum $\mathrm{E}_{2}, \mathrm{FSH}$ and $\mathrm{LH}$ concentrations between immature and mature whales. These results suggest that it is not possible to assess sexual maturity by serum T, E2, FSH and $\mathrm{LH}$ concentrations in captured common minke and Bryde's whales during the feeding season. In addition, these results indicate the possibility that there is no significant difference in basal hormone concentrations during the feeding season between immature and mature whales.
FSH is known to stimulate Sertoli cell proliferation and initiate testicular growth [22, 23]. In bottlenose dolphins, Schneyer et al. [24] reported that serum FSH and LH concentrations reflected seasonal differences and showed higher values in early summer (Gulf of Mexico population) than in the fall (Indian River, Florida population). In roe deer, the peaks of FSH and LH occur before the rutting period to stimulate spermatogonial proliferation, and the $\mathrm{T}$ peak is coincident with the period of maximal sperm production [25]. In the present study, a single-layer of spermatogonia was observed in seminiferous tubules of common minke and Bryde's whales. In male Djungarian hamsters exposed to short-day photoperiods, FSH treatment induced normal spermatogenesis despite low testicular $\mathrm{T}$ concentrations [26]. In mature short-finned pilot whales, it was reported that testicular and serum $\mathrm{T}$ levels were $128.64 \pm 28.73$ $\mathrm{ng} / \mathrm{g}$ and $5.43 \pm 1.18 \mathrm{ng} / \mathrm{ml}$, respectively [16]. In the present study, a few spermatozoa were observed in seminiferous tubules of common minke and Bryde's whales even with low or undetectable $\mathrm{T}$ concentrations. Two possibilities are considered for this observation. First, sperm production might have occurred during the feeding season in the whales even with low FSH and T concentrations. Second, the spermatozoa observed in this study might have been produced during the previous breeding season, and remained in the seminiferous tubules which degenerated during the non-breeding season. From the histological observations, we considered that during the feeding season, spermatogenesis did not take place along with the low $\mathrm{T}$ concentrations in both common minke and Bryde's whales, although the histological sections of the two whales were similar with the presence of spermatozoa in the seminiferous tubules.

In Antarctic minke whales, the proportion of whales with motile and immotile spermatozoa in vasa deferentia decreased from December to February, and remained low (about $0 \%$ ) in March [7]. In the present study, common minke and Bryde's whales with spermatozoa in seminiferous tubules were captured from May to June and from June to July, respectively. The Bryde's whale with motile spermatozoa in the vasa deferentia was captured in July. Therefore, we consider that the peak of the breeding season in common minke and Bryde's whales would be after September and 
October, respectively, if the results of Antarctic minke whales [7] were applicable to common minke and Bryde's whales.

In seasonal breeders such as bucks [6] and red deer [27], seminiferous tubule diameter indicates activity of spermatogenesis. In the present study, the mean seminiferous tubule diameter in mature common minke and Bryde's whales were $142.7 \pm$ $2.9 \mu \mathrm{m}$ and $179.8 \pm 11.8 \mu \mathrm{m}$, respectively. However, it is not clear whether the seminiferous tubule diameter indicates spermatogenesis activity in northern baleen whales. Also, the seminiferous tubule number of mature common minke whales was higher than that of Bryde's whales, and the seminiferous tubule diameter of mature common minke whales was smaller than that of Bryde's whales. It is likely that seminiferous tubule density of common minke whales is larger than Bryde's whales in mature individuals. We consider that seminiferous tubule density reflects the testis size.

Post freezing-thawing characteristics and morphology of spermatozoa from Antarctic minke whale $[4,20]$ and morphology of Bryde's whale spermatozoa [28] were reported previously. In the present study, normal sperm heads of Bryde's whale spermatozoa were conical or elliptic in form as in previous studies of Antarctic minke [4] and Bryde's [28] whales. These results suggest the possibility that the head shapes of Bryde's whale spermatozoa resemble those of Antarctic minke whale spermatozoa. In the present study, the post freezing-thawing characteristics of sperm from a Bryde's whale were higher in viability and morphological sperm normality, compared with Antarctic minke whales. As the post freezingthawing sperm concentration, motility, viability and abnormality varies in individual male whales, sperm characteristics may depend on the initial spermatozoa quality before cryopreservation. In the future, the cryopreservation method needs to be improved because the post thawing sperm motility was low ( $<5 \%$ in motility) as compared with Antarctic minke whales (2-40\%) [20]. However, the present results indicate that the post freezingthawing spermatozoa taken from vasa deferentia of Bryde's whale have kept motility and normal morphology.

In conclusion, the present study indicates that the serum T, E2, FSH and LH concentrations can not be used as indicators of reproductive activity in common minke and Bryde's whales during the feeding season. However, some spermatozoa were observed in seminiferous tubules of common minke and Bryde's whales with low or undetectable levels of T. Also, there were no significant differences in basal $\mathrm{E}_{2}, \mathrm{FSH}$ and $\mathrm{LH}$ concentrations between immature and mature whales, and between mature common minke and Bryde's whales. It is expected that the present results will provide useful information for understanding reproductive status during the feeding season and for establishing reproductive techniques in baleen whales.

\section{Acknowledgments}

The authors thank the crew of the research base ship, Nisshin-maru for blood and testis sampling of common minke and Bryde's whales used in this study, and Dr. T. Matsui, Laboratory of Veterinary Pathology, Obihiro University of Agriculture and Veterinary Medicine, Obihiro, Japan for preparing the histological slides.

\section{References}

1. Fukui $\mathbf{Y}$, Mogoe T, Ishikawa $\mathbf{H}$, Ohsumi S. In vitro fertilization of in vitro matured minke whale (Balaenoptera acutorostrata) follicular oocytes. Mar Mamm Sci 1997; 13: 395-404.

2. Mogoe T, Fukui Y, Ishikawa H, Ohsumi S. Effects of diluent composition and temperature on motility and viability after liquid storage and cryopreservation of minke whale (Balaenoptera acutorostrata) spermatozoa. Mar Mamm Sci 1998; 14: 854-860.

3. Asada $\mathbf{M}$, Tetsuka $\mathbf{M}$, Ishikawa $\mathbf{H}$, Ohsumi $\mathbf{S}$,
Fukui Y. Improvement on in vitro maturation, fertilization and development of minke whale (Balaenoptera acutorostrata) oocytes. Theriogenology 2001; 56: 521-533.

4. Mogoe T, Fukui Y, Ishikawa H, Ohsumi S. Morphological observations of frozen-thawed spermatozoa of southern minke whales (Balaenoptera acutorostrata). J Reprod Dev 1998; 44: 95100.

5. Boland MP, Al-Kamali AA, Crosby TF, Haynes NB, Howles CM, Kelleher DL, Gordon I. The 
influence of breed, season and photoperiod on semen characteristics, testicular size, libido and plasma hormone concentrations in rams. Anim Reprod Sci 1985; 9: 241-252.

6. Walkden-Brown SW, Restall BJ, Taylor WA. Testicular and epididymal sperm content in grazing Cashmere bucks: seasonal variation and prediction from measurements in vivo. Reprod Fertil Dev 1994; 6: 727-736.

7. Mogoe T, Suzuki T, Asada M, Fukui Y, Ishikawa $\mathbf{H}$, Ohsumi S. Functional reduction of the southern minke whale (Balaenoptera acutorostrata) testis during the feeding season. Mar Mamm Sci 2000; 16: 559-569.

8. Kato H. Study on changes in biological parameters and population dynamics of southern minke whales. Ph.D. thesis, Hokkaido University 1986 (In Japanese).

9. Nishiwaki M, Hibiya T, Kimura S. On the sexual maturity of sei whale of the Bonin waters. Sci Rep Whales Res Inst 1954; 9: 165-177.

10. Iga K, Fukui Y, Miyamoto A, Ishikawa H, Ohsumi S. Endocrinological observations of female minke whales. Mar Mamm Sci 1996; 12: 296-301.

11. Wijayagunawardane MP, Miyamoto A, Cerbito WA, Acosta TJ, Takagi M, Sato K. Local distributions of oviductal estradiol, progesterone, prostaglandins, oxytocin and endothelin-1 in the cyclic cow. Theriogenology 1998; 49: 607-618.

12. Watanabe H., Miyamoto A, Fukui Y. A competitive enzymeimmunoassay for follicle-stimulating hormone in ovine plasma using biotinstreptavidine amplification. Reprod Fertil Dev 1997; 9: 597-601.

13. Suzuki T, Mogoe T, Asada M, Miyamoto A, Tetsuka M, Ishikawa H, Ohsumi S, Fukui Y. Plasma and pituitary concentrations of gonadotropins (FSH and LH) in minke whales (Balaenoptera acutorostrata) during the feeding season. Theriogenology 2001; 55: 1127-1141.

14. Mutayoba BM, Meyer HH, Schams D, Schallenberger E. Development of a sensitive enzyme immunoassay for LH determination in bovine plasma using the streptavidin-biotin technique. Acta Endocrinol (Cph) 1990; 122: 227-232.

15. Christensen I. Age determination of minke whales, Balaenoptera acutorostrata, from laminated structures in the tympanic bullae. Rep Int Whale Commn 1981; 32: 245-253.

16. Kita S, Yoshioka M, Kashiwagi M. Relationship between sexual maturity and serum and testis testosterone concentrations in short-finned pilot whales Globicephala macrorhynchus. Fish Sci 1999; 65: 878-883.

17. Desportes G, Saboureau M, Lacroix A. Growthrelated changes in testicular mass and plasma testosterone concentrations in long-finned pilot whales, Globicephala melas. J Reprod Fertil 1994; 102: 237-244.

18. Morais RN, Mucciolo RG, Gomes MLF, Lacerda O, Moraes W, Moreira N, Graham LH, Swanson WF, Brown JL. Seasonal analysis of semen characteristics, serum testosterone and fecal androgens in the ocelot (Leopardus pardalis), margay (L. wiedii) and tigrina (L. tigrinus). Theriogenology 2002; 57: 2027-2041.

19. Olafsson I, Kjeld M. Serum progesterone and testosterone levels in fin whales (Balaenoptera Physalus). Isr J Vet Med 1986; 42: 300-306.

20. Fukui Y, Mogoe T, Jung YG, Terawaki Y, Miyamoto A, Ishikawa $H$, Fujise $Y$, Ohsumi $S$. Relationship among morphological status, steroid hormones, and post-thawing viability of frozen spermatozoa of male minke whales (Balaenoptera acutorostrata). Mar Mamm Sci 1996; 12: 28-37.

21. Yoshioka M, Fujise Y. Serum testosterone and progesterone levels in southern minke whales (Balaenoptera acutorostrata). The 44th IWC Scientific Committee; 1992; Document SC/44/SHB13: 4.

22. Arslan M, Weinbauer GF, Schlatt S, Shahab M, Nieschlag E. FSH and testosterone, alone or in combination, initiate testicular growth and increase the number of spermatogonia and Sertoli cells in a juvenile non-human primate (Macaca mulatta). J Endocrinol 1993; 136: 235-243.

23. Ultee-van Gessel AM, Timmerman MA, de Jong FH. Effects of treatment of neonatal rats with highly purified FSH alone and in combination with $\mathrm{LH}$ on testicular function and endogenous hormone levels at various ages. J Endocrinol 1988; 116: 413-420.

24. Schneyer A, Castro A, Odell D. Radioimmunoassay of serum follicle-stimulating hormone and luteinizing hormone in the bottlenosed dolphin. Biol Reprod 1985; 33: 844-853.

25. Roelants H, Schneider F, Göritz F, Streich J, Blottner S. Seasonal changes of spermatogonial proliferation in roe deer, demonstrated by flow cytometric analysis of c-kit receptor, in relation to follicle-stimulating hormone, luteinizing hormone, and testosterone. Biol Reprod 2002; 66: 305-312.

26. Lerchl A, Sotiriadou S, Behre HM, Pierce J, Weinbauer GF, Kliesch S, Nieschlag E. Restoration of spermatogenesis by follicle-stimulating hormone despite low intratesticular testosterone in photoinhibited hypogonadotropic Djungarian hamsters (Phodopus sungorus). Biol Reprod 1993; 49: 1108-1116.

27. Hochereau-de Reviers MT, Lincoln GA. Seasonal variation in the histology of the testis of the red deer, Cervus elaphus. J Reprod Fertil 1978; 54: 209-213.

28. Kita S, Yoshioka M, Kashiwagi M, Ogawa S, Tobayama T. Comparative external morphology of cetacean spermatozoa. Fish Sci 2001; 67: 482-492. 